\title{
PENGARUH PERANCANGAN ULANG TATA LETAK FASILITAS DI AREA OPERASIONAL KERJA BERBASIS 5S UNTUK PENGAJUAN MODAL USAHA
}

\section{THE EFFECT OF LAYOUT FACILITIES IN THE 5-BASED WORKING AREA FOR SUBMISSION OF BUSINESS CAPITAL}

\author{
Risthia Eriana Putri ${ }^{1}$, Widodo Ismanto ${ }^{2}$ \\ ${ }^{1,2}$ Prodi Magister Manajemen, Pascasarjana, UNRIKA, Indonesia \\ Email: risthia.eriana.putri@gmail.com
}

\begin{abstract}
Abstrak
Penelitian ini bertujuan untuk mengetahui apakah perancangan ulang Tata Letak fasilitas di area operasional pada sebuah tempat usaha atau industri dapat menentukan Efektifitas dan Efisiensi operational produksi dimana lahan yang dimiliki sangat terbatas, hingga pengajuan untuk pembiayaan sebagai modal usaha di Bank. Perancangan fasilitas poduksi merupakan salah satu faktor yang sangat berpengaruh pada kinerja suatu perusahaan. Hal ini disebabkan oleh tata letak fasilitas yang kurang baik akan menyebabkan pola aliran bahan yang kurang baik dan perpindahan bahan, produk, informasi, peralatan dan tenaga kerja menjadi relatif tinggi yang menyebabkan keterlambatan penyelesaian produk dan menambah biaya produksi. Perancangan tata letak dalam sebuah usaha merupakan awalan utama dalam mengatur tata letak fasilitas produksi dan memanfaatkan area semaksimal mungkin. Hal ini dibuat untuk menciptakan kelancaran aliran bahan, sehingga nanti dapat diperoleh aliran bahan yang efisien dan kondisi kerja yang teratur.Penelitian ini menerapkan metode $5 S$ pada penyusunan tata letak fasilitas Alya Jaya Motor untuk memperoleh tata letak yang lebih rapi, yaitu Seiri dan Seiton pada gudang mekanik, Seiso yaitu pada gudang produksi dan semua departemen, Seiketsu dan Shitsuke. Sample dari penelitian ini adalah salah satu usaha kecil yang bergerak dalam jasa Cuci Motor dan Mobil yang ingin memperbesar usaha nya dengan meminta pembiayaan pada modal pada Bank.
\end{abstract}

Katakunci: Perancangan Ulang, Tata Letak, $5 S$

\begin{abstract}
This study aims to determine whether the redesign of the Plant Layout of facilities in the operational area of a business place or industry can determine the effectiveness and operational efficiency of production where the land is very limited, until the submission for financing as business capital in the Bank. The design of production facilities is one of the factors that greatly influence the performance of a company. This is due to the unfavorable facility layout which will cause a pattern of unfavorable material flow and the transfer of materials, products, information, equipment and labor to be relatively high which causes delays in the completion of products and increases production costs. The layout design in a business is the main prefix in arranging the layout of production facilities and utilizing the area to the maximum extent possible. This is made to create a smooth flow of material, so that later can be obtained by efficient flow of materials and regular working conditions. This study applies the $5 S$ method to the preparation of the Alya Jaya Motor facility layout to obtain a neater layout, namely Seiri and Seiton in the mechanical warehouse, Seiso namely in the production warehouse and all departments, Seiketsu and Shitsuke The sample of this study is one small business which is engaged in Motorcycle and Car Wash services that want to enlarge its business by asking for financing.
\end{abstract}

Keywords: Layout, Design Facilities, 5 S 


\section{PENDAHULUAN}

Perancangan fasilitas poduksi merupakan salah satu faktor yang sangat berpengaruh pada kinerja suatu perusahaan. Hal ini disebabkan oleh tata letak fasilitas yang kurang baik akan menyebabkan pola aliran bahan yang kurang baik dan perpindahan bahan, produk, informasi, peralatan dan tenaga kerja menjadi relatif tinggi yang menyebabkan keterlambatan penyelesaian produk dan menambah biaya produksi. Tata letak pabrik (layout) dapat didefinisikan sebagai tata cara pengaturan fasilitas-fasilitas pabrik guna menunjang kelancaran proses produksi (Hadiguna, 2008). Pengaturan tersebut akan memanfaatkan luas area untuk menempatkan mesin atau fasilitas penunjang produksi lainnya, kelancaran gerak perpindahan material baik bersifat temporer maupun permanen, personal pekerja dan lain sebagainya. Dalam tata letak pabrik terdapat 2 (dua) hal yang harus diperhatikan yaitu pengaturan mesin dan pengaturan departemen dalam pabrik.

Obyek yang diamati yaitu sebuah industri yang bergerak pada bidang jasa pencucian kendaraan yang bernama “Alya Jaya Motor" di Perawang, Pekanbaru. Lahan yang kurang memadai menjadi kendala pada saat pembagunan, akibatnya proses pelayanan menjadi sedikit terganggu. Oleh itu diperlukan pemikiran yang tepat agar nantinya usaha ini dapat berkembang dan mempunyai banyak pelanggan. Untuk bisa bersaing dengan para kompetitornya, dituntut adanya hasil proses pelayanan yang baik. Sehingga pemilik usaha mendukung adanya upaya-upaya perbaikan disemua fasilitas demi mencapai apa yang diinginkan. Untuk itu, diperlukan adanya efektifitas dan efisiensi kerja yang didukung dengan lahan ataupun area proses pelayanan yang memadai. Hal ini dapat dicapai salah satunya dengan mengoptimalkan tata letak fasilitas pada area proses pelayanan.

Setelah pabrik dipilih untuk menempati suat daerah dengan memperhitungkan berbagai faktor, maka adala hal lain yang harus diperhatikan yaitu bagaimana menempatkan tata letak pabrik dan tata letak fasilitas. Tata letak merupakan salah satu keputusan yang menentukan efisiensi dan efektifitas operasional perusahaan dalam jangka panjang.

Pentingnya rancangan fasilitas bagi operasi suatu perusahaan yang sangkil tidak dapat ditunjukkan. Harus diketahui bahwa aliran barang merupakan tulang punggung fasilitas 
produksi, dan harus dirancang dengan cermat serta tidak boleh dibiarkan tumbuh atau berkembang menjadi satu pola lalulintas yang membingungkan.

Suatu perencanaan efisien bagi aliran barang adalah prasyarat bagi produksi yang ekonomis. Pola aliran barang menjadi dasar bagi penyusunan fasilitas fisik yang efektif.Pemindahan barang merubah pola aliran statis kedalam kenyataan cergas, memberikan cara bagaimana barang dipindahkan.Susunan fasilitas yang sangkil disekitar pola aliran barang dapat menghasilkan pelaksanaan berbagai proses yang berkaitan secara efisien.Penyelesaian proses yang sangkil dapat meminimumkan biaya produksi.Biaya produksi minimum dapat memberikan keuntungan maksimal.

Tata letak pabrik merupakan salah satu bagian terbesar dari suatu studi perancangan fasilitas. Perancangan Fasilitas sendiri terdiri dari pelokasian pabrik dan perancangan gedung dimana sebagaimana diketahui bahwa antara letak pabrik dengan penanganan material saling berkaitan erat. Dalam suatu pabrik banyak dijumpai berbagai macam faslitas produksi agar suatu kegiatan berjalan lancar, baik berupa mesin, peralatan produksi, pekerja dan fasilitas penunjang lainnya yang harus disediakan dan ditempatkan pada tempat masing-masing agar berfungsi secara optimal.

Penyusunan tata letak yang baik dapat memperlihatkan suatu penyusunan daerah kerja yang paling ekonomis untuk dijalankan, disamping itu akan menjamin keamanan dan kepuasan kerja dari karyawan.Bagi pengusaha hasil penelitian ini diharapkan dapat memberikan sumbangan pemikiran untuk dijadikan sebagai suatu masukan dan saran, yang dapat dijadikan suatu pertimbangan oleh pengusaha dalam melakukan perubahan tata letak.

\section{Tujuan Penelitian}

1. Menganalisis tata letak masing-masing fasilitas.

2. Mengetahui jumlah kendaraan yang dapat ditampung pada area sebelum dan sesudah perencanaan perbaikan ulang tata letak fasilitas di area proses pelayanan.

3. Membuat usulan perbaikan tata letak di area proses pelayanan.

4. Membuat pengajuan kepada Bank untuk pembiayaan modal usaha 


\section{TINJAUAN PUSTAKA}

\section{Tata Letak}

Menurut Setyoningsih dan Almahdy (2005), bahwa tata letak yang efektif dapat membantu perusahaan dalam mencapai hal-hal berikut:

1. Pemanfaatan yang lebih besar atas ruangan, peralatan dan manusia.

2. Arus informasi, bahan baku, dan manusia yang lebih baik.

3. Lebih memudahkan konsumen.

4. Peningkatan moral karyawan, dan kondisi kerja yang lebih aman.

\section{Design Facitilies}

Istilah ataupun pengertian desain suatu pabrik (plant design) dan pengaturan tata letak pabrik (plant layout) sering kali membingungkan dan diartikan sama. Kedua istilah ini sebenarnya memiliki arti yang berbeda meskipun ada kaitannya satu dengan lainnya. Dengan perencanaan pabrik dan ada yang lebih luas lagi, yaitu meliputi (Aiello, 2007):

1. Perencanaan financial

2. Bantuan lokasi pabrik

3. Seluruh perencanaan yang diperlukan untuk memenuhi kebutuhan-kebutuhanfisik pabrik.

Sedangkan tujuan utama dalam desain tata letak pabrik pada dasarnya adalah untuk meminimalkan total biaya yang antara lain menyangkut elemen-elemen biaya sebagai berikut (Wignjosoebroto, 2000):

1. Biaya untuk konstruksi dan instalasi baik untuk bangunan mesin, maupun fasilitas produksi lainnya.

2. Biaya pemindahan bahan.

3. Biaya produksi, maintenance, safety, dan biaya penyimpanan produk setengah jadi.

\section{Tahapan Perencanaan Tata Letak Pabrik}

Operation Process Chart (OPC), Chart ini digunakan dalam menganlisa aliran operasi bahanyang terjadi pada proses produksi. Peta ini menggambarkan gambaran grafis paling lengkap dari seluruh proses. Adapun pembentukan peta proses aliran sebagai (Wignjosoebroto, 2009) dapatkan proses operasi dari proses yang tengah dikaji, dapatkan peta 
proses umum tiap komponen, gambarkan kembali peta proses operasi pada garis yang sesuai dengan komponen, masukkan seluruh data yang diinginkan di sisi lambang, seperti uraian, jarak, jumlah, waktu, biaya dan sebagainya, kaji peta yang dihasilkan untuk memungkinkan perbaikan dari seluruh proses, keterkaitan antara kegiatan, proses mandiri dan sebagainya.

Activity Relationship Chart, peta hubungan aktivitas atau activityrelationship chart (selanjutnya disingkat dengan ARC) adalah suatu cara atau teknik yang sangat sederhanan di dalam merencanakan tata letak fasilitas atau departemen berdasarkan derajat hubungan aktivitas "kualitatif" dan cenderung berdasarkan pertimbangan yang bersifat subjektif dari masing-masing fasilitas departemen (Wignjosoebroto, 2000).

Work sheet disusun berdasarkan apa yang telah ditetapkan dalam activity relationship chart yang terdidri dari baris dan kolom dan pada bagian sebelah kiri ditempatkan urutan kegiatan sedang pada bagian kanan ditempatkan tingkat hubungan. Baris-baris dan kolom ini lebih mudah dilihat hubungan antara aktivitas dengan melihat pada kolom alasan dibawahnya. (James, 1990).

Block template merupakan kelanjutan dari worksheet dimana masing-masing aktivitas dibuatdalam suatu bujur sangkar atau persegi panjang. Nomor kode tiap kegiatan/aktivitas dituliskan di tengah-tengah dari block sedang tingkat hubungan dituliskan pada sudut block template tersebut (Purnomo, 2004).

Activity Relationship Diagram (Rel Diagram), data yang telah dikelompokkan dalam work sheet kemudian dimasukkan ke dalam suatu activity template. Tiap-tiap template akan menjelaskanmengenai departemen yang bersangkutan dan hubungan dengan aktivitas dari departemen-departemen yang lain. Template disini hanya bersifat memberi penjelasan mengenai hubunganaktivitas antar departemen satu dengan departemen yang lain, untuk itu skala luasan dari masing-masing departemen tidak perlu diperhtaikan benar, (Wignjosoebroto, 2009).

Production Space Requirement Sheet (PSRS), menganalisis luas lantai yang dibutuhkan olehsetiap kegiatan. Pada sheet ini juga dapat dilihat luas lantai yang dibutuhkan oleh mesin, operator dan alat bantu dari setiap kegiatan. (James, 1990). 
Plant Service Area Planning Sheet (PSAPS), sheet ini digunakan untuk menganalisa luaslantai yang diperlukan untuk kegiatan servis. Kegiatan servis ini meliputi (James, 1990) productionservice (servis untuk produksi), general servis (servis untuk umum) dan personal servis (servisuntuk keperluan pribadi).

Total Space Requerement Sheet (TSRWS), dalam mengestimasi luas lantai yang diperlukanuntuk masing-masing aktivitas serta ukuran dari template maka digunakan sheetini.Total spacerequirement work sheet ini merupakan gabungan hasil penganalisis pada production space requirement sheet dan plant service area planning sheet diatas, (James, 1990).

Area Template, Template adalah suatu skala representasi dalam bentuk dua dari suatu objekfisik yang dibuat untuk keperluan desain layout.Yang dimasud dengan objek fisik disini bisa berupa mesin, peralatan material handling, manusia dan fasilitas lainnya, (Wignjosoebroto, 2000).

Space Relationship Diagram, dalam space rel ini diganbarkan tentang kedekatan dengangaris yang merupakan kelanjutan dari pembentukan activity relationship diagram.Diagram digambarkan dalam bentuk template disertai dengan ukuran departemen sesuai dengan luas area yang dihitung.

Final layout merupakan tahap akhir perencanaan, di final layout terlihat secara lengkap danjelas setiap bagian dan ruangan-ruangan serta fasilitas yang diperlukan oleh perusahaan mulai dari bahan baku, proses produksi, administrasi dan fasilitas penunjang lainnya yang dapat menunjang kegiatan produksi dapat berjalan dengan baik dan lancar efektif, (James, 1990).

\section{Definisi Kaizen Tentang Metode 5S}

Kaizen merupakan alat pemersatu filsafat, sistem dan alat untuk memecahkan masalah yangdikembangkan di Jepang selama 30 tahun pada suatu perusahaan untuk berbuat lebih baik lagi. Kaizen dapat dimulai dengan menyadari bahwa setiap perusahaan mempunyai masalah. Kaizen memecahkan masalah dengan membentuk kebudayaan perusahaan dimana setiap orang dapat mengajukan masalahnya dengan bebas (Meyers, 1993). Definisi yang luas dari 5S adalah memanfaatkan tempat kerja (yang mencakup peralatan, dokumen, bangunan dan ruang) 
untuk melatih kebiasaan para pekerja dalam usaha meningkatkan disiplin kerja yang dimulai dengan Pemilahan (Seiri), Penataan (Seiton), Pembersihan (Seiso), Pemantapan (Seiketsu), Disiplin (Shitsuke) atau telah ikut serta sepenuhnya dalam pengembangan kebiasaankebiasaan kerja yang baik sesuai aturan yang ditetapkan (Meyers, 1993).

\section{Efektifitas dan Efisiensi}

Prinsip dasar dari perencanaan tata letak pabrik merupakan tujuan dari perencanaan tata laetak pabrik itu sendiri. Prinsip - prinsip itu antara lain Wignjoesoebroto (1990):

1. Prinsip integrasi total

Prinsip ini menyatakan bahwa tata letak pabrik adalah integrasi secara total dari seluruh elemen produksi yang ada menjadi satu unit operasi yang besar.

2. Prinsip jarak pemindahan yang minimal

Dalam proses pemindahan dari suatu unit operasi ke unit operasi lain, waktu dapat dihemat dengan cara mengurangi jarak perpindaha tersebut.

3. Prinsip aliran dari suatu proses kerja

Dengan prinsip ini diusahakan adanya gerakan balik, gerakan memotong.

4. Prinsip pemanfaatan ruangan

Dalam merencanakan tata letak pabrik, kita harus mempertimbangkan faktor-faktor dimensi ruang serta gerakan dari orang, bahan, atau mesin.

5. Prinsip kepuasan dan keselamatan kerja

Kepuasan dan keselamatan kerja yang terjamin akan memberikan moral kerja yang lebih baik dari karyawan dan hal ini akan mengurangi ongkos produksi serta meningkatkan kemauan kerja karyawan sehingga otomatis perusahaan akan mendapat keuntungan ganda.

\section{Pembiayaan Bank dan Lembaga Keuangan Lainnya}

Menurut Undang-Undang Perbankan Nomor 10 tahun 1998 "kredit adalah penyedian uang atautagihan yang dapat dipersamakan dengan itu,berdasarkan persetujuan atau kesepakatan pinjammeminjam antara bank dengan pihak lain yangmewajibkan pihak peminjam melunasi utangnyasetelah jangka waktu tertentu dengan pemberian Bunga". Sedangkan pengertian "pembiayaan adalahpenyedian uang atau tagihan yang dapat 
dipersamakan dengan itu, berdasarkan persetujuan atau kesepakatanantara bank dengan pihak lain yang mewajibkan pihakyang dibiayai untuk mengembalikan uang atautagihan tersebut setelah jangka waktu tertentu denganimbalan atau bagi hasil", (Ratnasari, 2012)

\section{Metode Penelitian}

Metode yang digunakan metode rancangan konvensional dengan penerapan metode 5S, yaitu Seiri (pemilihan) diterapkan pada ruang mekanik yaitu meletakkan peralatan pada tempatnya dan minyisihkan yang tidak perlu sehingga tidak membutuhkan waktu yang lama dalam menyelesaikan tugasnya, Seiton (penataan) yaitu barang-barang yang telah melewati proses seiri dilanjutkan dengan proses penataan peralatan yang telah dipilih tersebut, Seiso (pembersihan) dilakukan pembersihan pada lantai produksi dan peralatan yang diperlukan pada proses produksi seperti mesin dan lain-lain, Seiketsu (pemantapan) disini dilakukan pemantapan terhadap metode $5 \mathrm{~S}$ yang telah diterapkan, supaya penerapan metode $5 \mathrm{~S}$ yang telah dilakukan tetap berlangsung terus menerus dan juga dilakukan pembuatan garis batas area kerja yang bertujuan agar penyusunan peralatan kerja lebih tertata dengan baik dan Shitsuke (pembiasaan) pada bagian ini lebih difokuskan bagaimana untuk membiasakan diri terhadap penerapan metode $5 \mathrm{~S}$.

Pada penelitian ini terdapat beberapa metode pengumpulan data yang dilakukan untuk mendapatkan data yang obyektif dan akurat, antara lain sebagai berikut:

1. Metode Observasi atau Pengamatan

Metode Observasi atau Pengamatan secara langsung untuk menganalisa dan mengetahui kondisi yang terjadi dilapangan. Hal ini penting dilakukan untuk mengetahui permasalahan yang akan terjadi dengan membandingkan kondisi yang terjadi dilapangan terhadap teori-teori yang digunakan.

2. Metode Penelitian Evaluasi

Penelitian Evaluasi ini dilakukan untuk menilai suatu program yang sedang atau sudah dilakukan. Dalam hal ini peneliti akan menggunakan data hasil observasi untuk perbaikan cara kerja.

Dalam observasi atau pengamatan secara langsung, peneliti akan mengumpulkan data-data utama dari penelitian sehingga hasil dari kegiatan ini adalah bahan-bahan yang selanjutnya 
akan diolah dan dianalisa untuk menyelesaikan permasalahan yang muncul. Dimana data-data yang akan diambil terbagi atas 2 bentuk yaitu data primer dan data sekunder .

a. Data Primer berupa

- Data Fasilitas apa saja yang dimiliki

- Data gambar tata letak fasilitas tersebut

- Data luas lahan masing-masing fasilitas

b. Data Sekunder berupa

- Data peralatan yang digunakan untuk proses pencucian

- Data luas lahan yang dimiliki sebagai tempat berdirinya pabrik.

- Data jumlah kendaraan yang masuk setiap hari nya. 


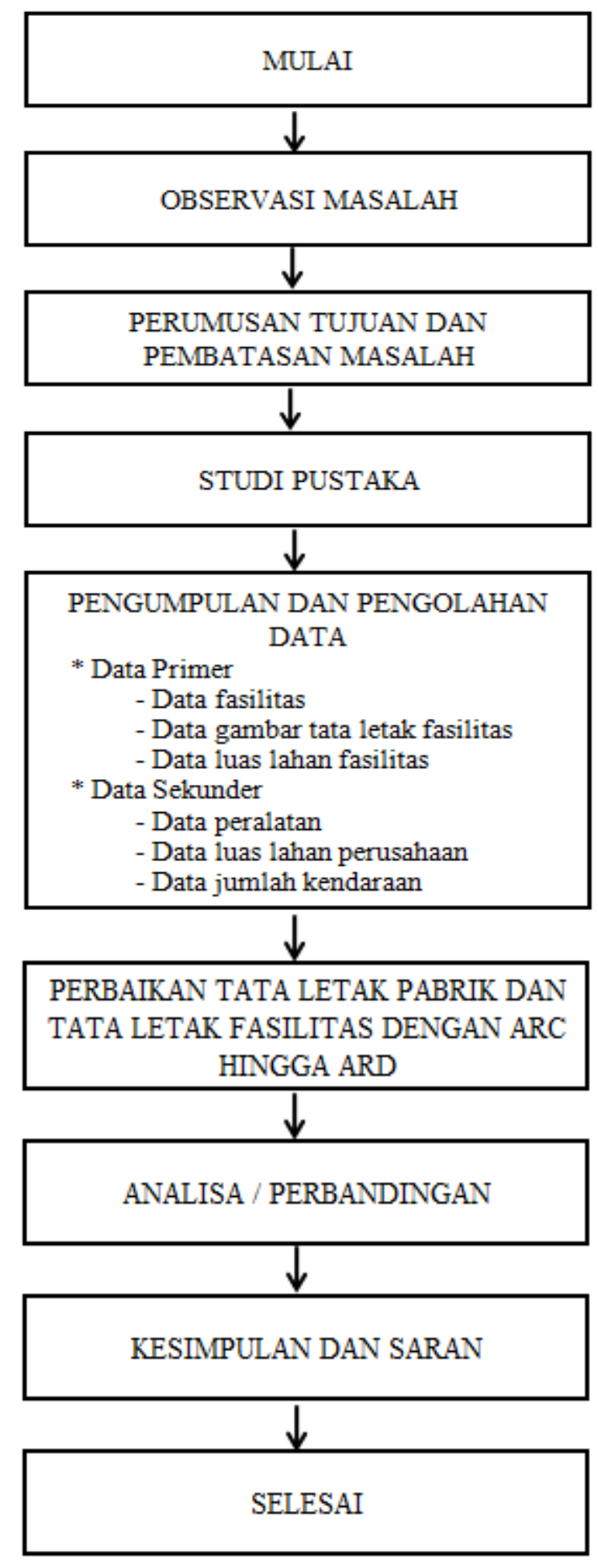

Gambar 1 Flow Chart Langkah Penelitian 


\section{Hasil Dan Pembahasan}

\section{Peta Proses Operasi (Operation Process Chart)}

Peta aliran proses disini lebih banyak digunakan sebagai alat untuk mengetahui proses kerja oleh karyawan pada stasiun kerja masing-masing, dengan adanya peta aliran proses ini karyawan yang baru kerja sekalipun dapat membaca peta dengan satu hingga dua kali training. kut peta aliran proses di Alya Jaya Motor:

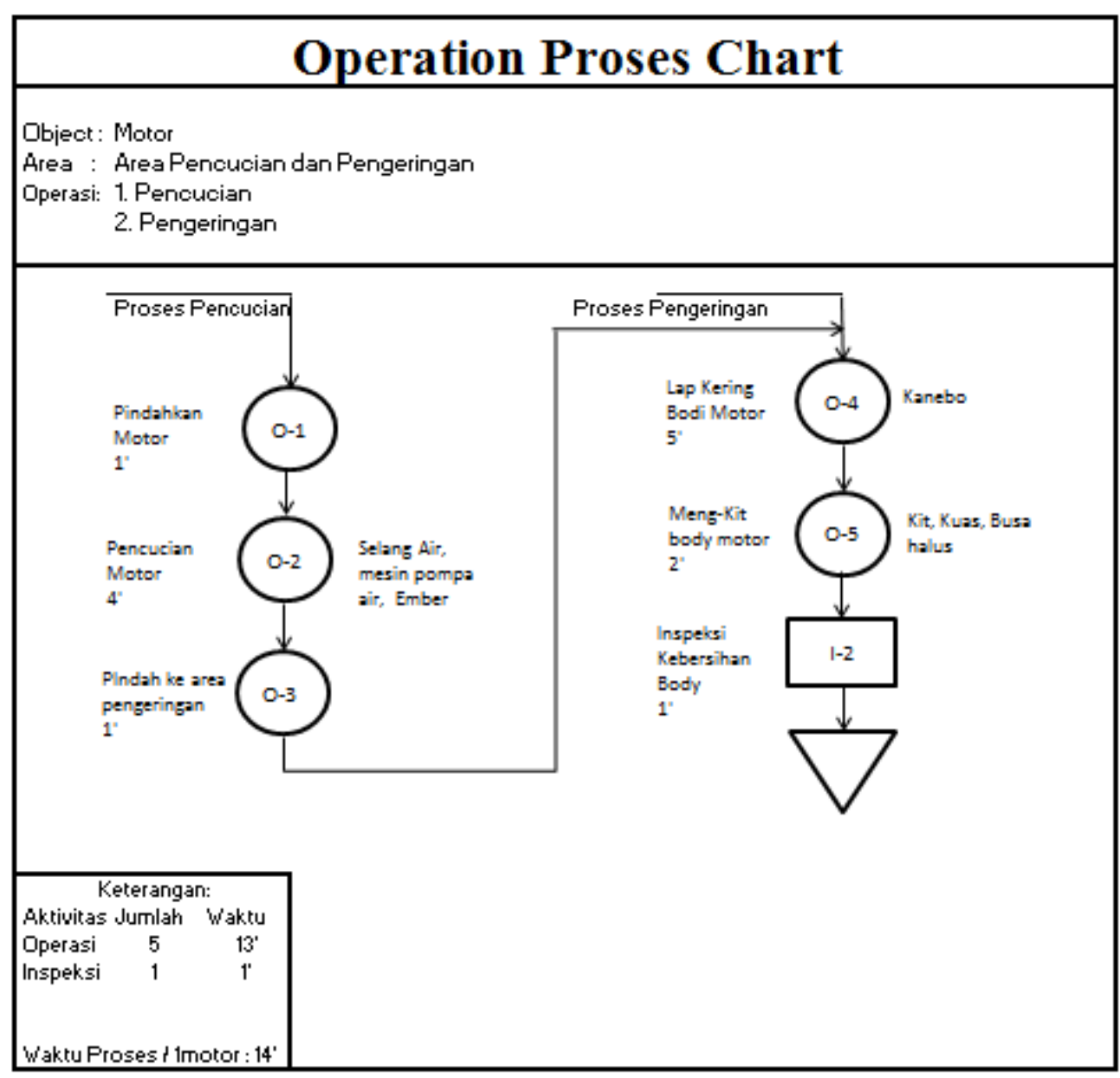




\section{Operation Proses Chart}

Object: Mobil

Area : AreaPencucian dan Pengeringan

Operasi: 1. Pencucian

2. Pengeringan

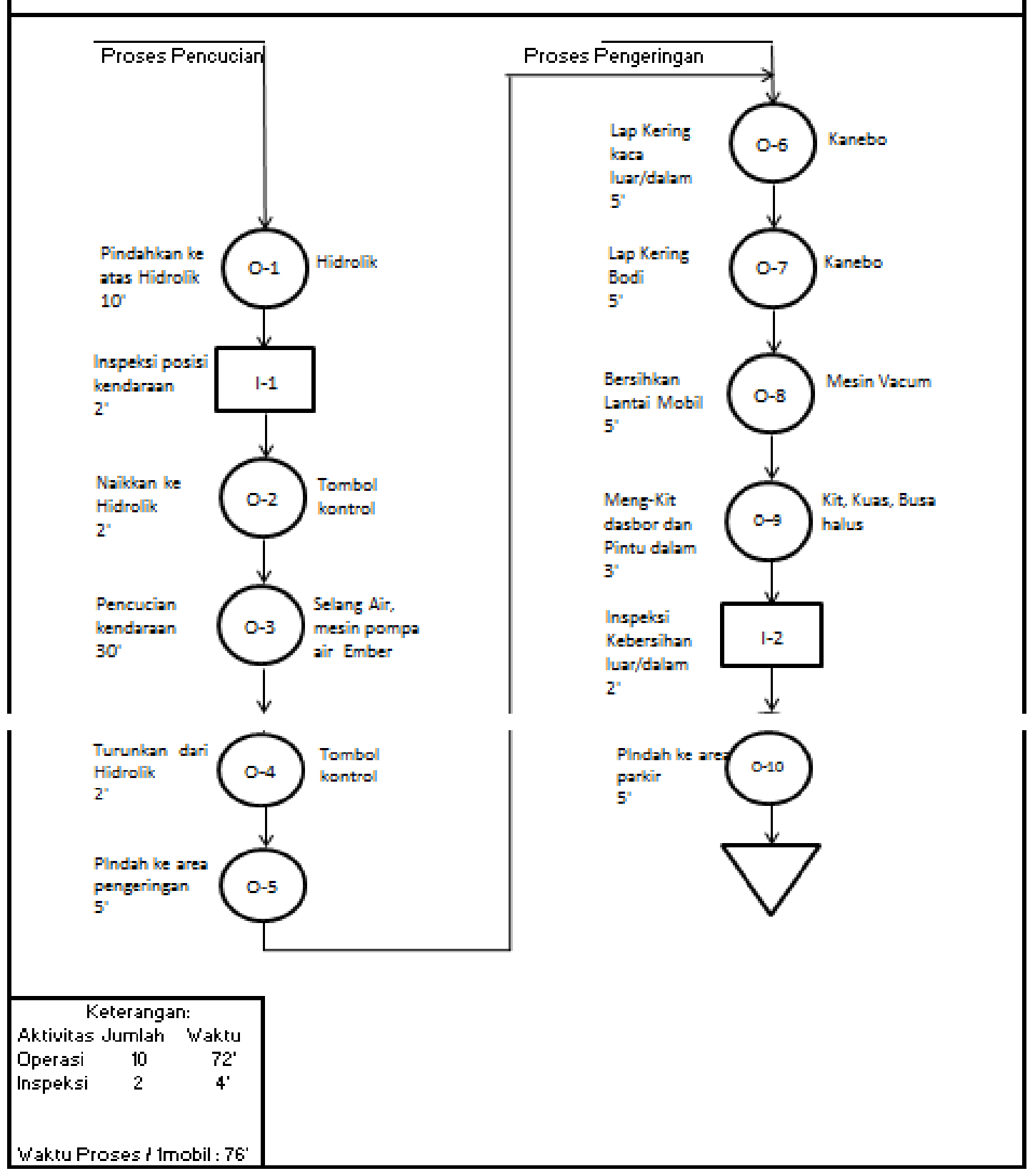




\section{Layout Awal}

Alya Jaya Motor yang memiliki luas $675 \mathrm{M}^{2}$ dengan lebar $15 \mathrm{M}^{2}$ x panjang $45 \mathrm{M}^{2}$ ini memiliki beberapa fasilitas yang harus direka ulang. Setiap fasilitas yang berhubungan dengan proses pelayanan produksi yang saat ini berada saling berdekatan dan berada pada satu lantai. Beberapa fasilitas yang berkaita erat dengan proses pelayanan produksi perlu dibenahi agar mendapatkan tata letak yang efisien. Berikut gambar tata letak nya sebelum dilakukan perancangan ulang tata letak fasilitas.

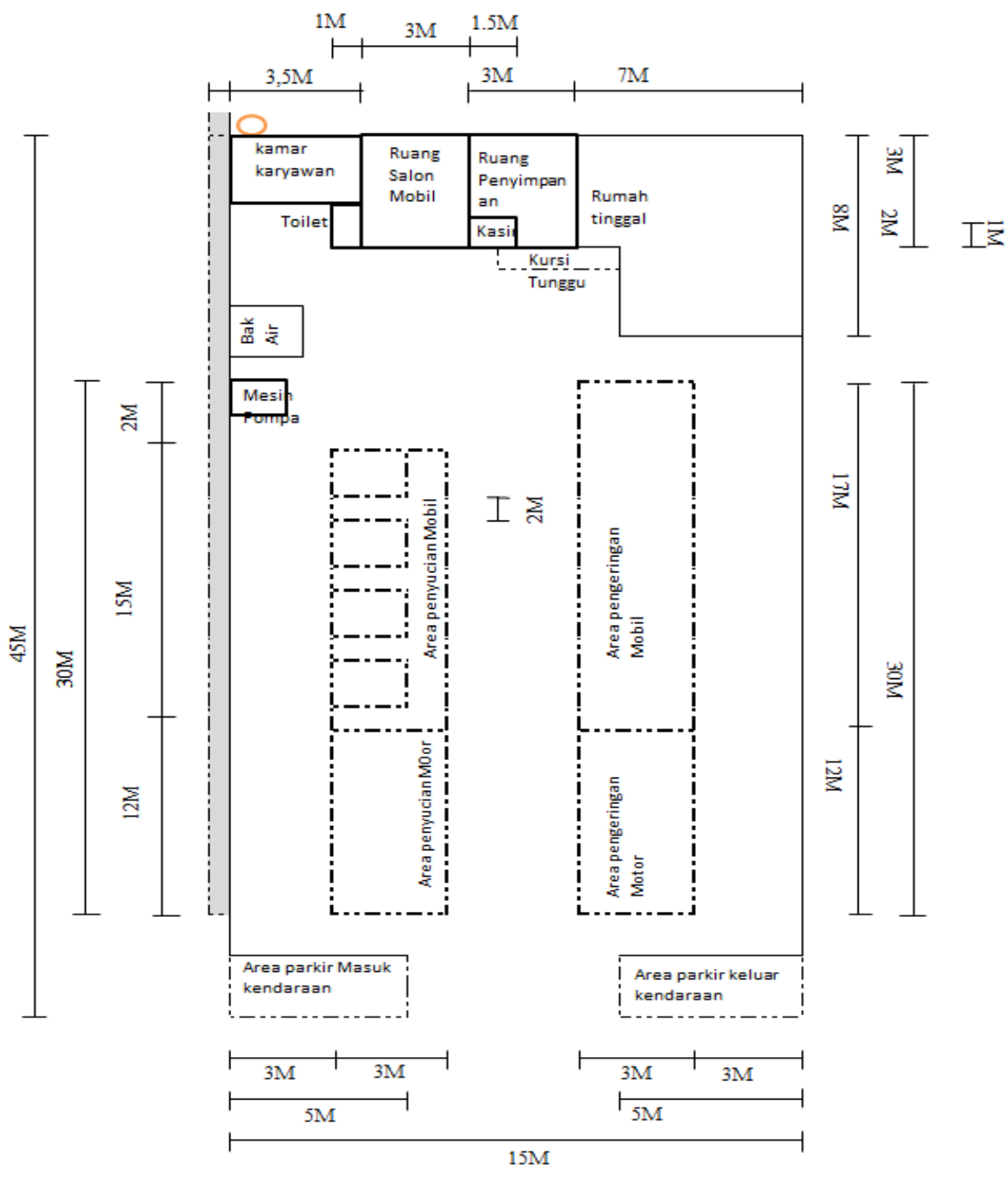


DIMENSI, VOL. 8, NO. $1: 71-89$

MARET 2019

ISSN: 2085-9996

\section{Activity Relationship Chart (ARC)}

Sebelum berhubungan dengan keterkaitan kegiatan tertentu, sebaiknya kita mengenali terlebih dahulu jenis-jenis keterkaitan yang ada diantara beberapa kegiatan.pada Alya Jaya Motor, hubungan antar kegiatan terbagi menjadi tiga kelompok besar yaitu: antara kegiatan produksi pelayanan, kegiatan pelayanan administrasi maupun kegiatan tambahan.

Pelayanan Produksi

1. Area pencucian motor / mobil

2. Area pengeringan motor / mobil

3. Area parkir kendaraan

4. Ruang Salon mobil

5. Kasir

6. Ruang Penyimpanan

7. Rumah tinggal

8. Kamar Karyawan

9. Toilet

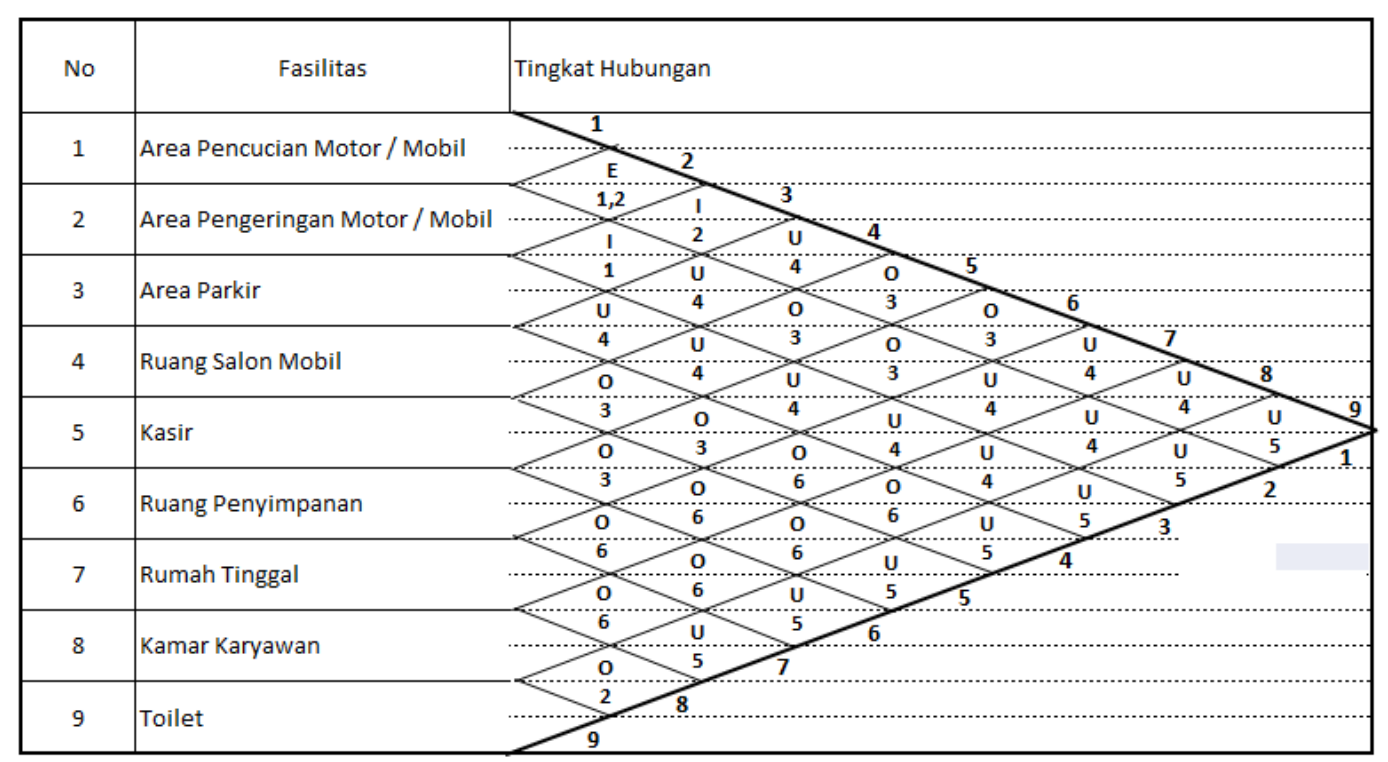




\section{BlockLayout}

Untuk lebih memudahkan analisa perancangan ulang tata letak fasilitas pada area pelayanan maka penulis membuat block layout perkiraan luas area yang dibutuhkan.Berikut adalah block layout yang menggambarkan pada area proses pelayanan sebelum dirancang ulang:

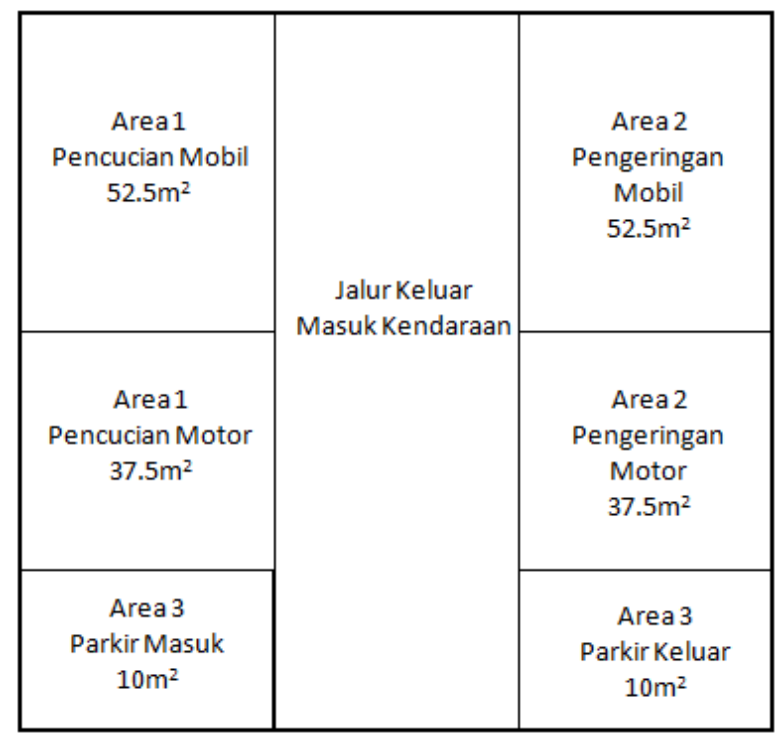

Gambar 2 Block Layout Sebelum

Block layout diatas akan dimodifikasi berdasarkan kebutuhan ruangan dan area yang didapat dari hasil rekapitulasi luas area yang dibutuhkan dan luas area yang tersedia. Didapatkan bahwa hasil rekapitulasi pada Area 2 dan Area 3 membutuhkan lahan lebih luas untuk meningkatkan proses pelayanan. Dengan demikian, dilakukan modifikasi block layout pada area tersebut. 


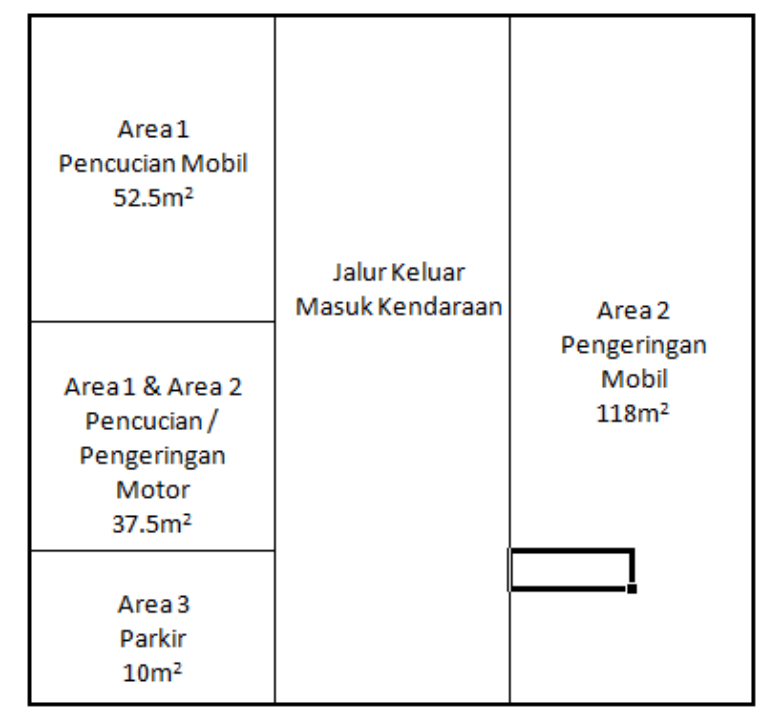

\section{Gambar 3 Block Layout Sesudah}

Kemudian dilanjutkan dengan analisis metode 5S. Adapun penerapan metode 5S diterapkan adalah sebagai berikut:

\section{Seiri (pemilihan)}

Metode Seiri diterapkan untuk memperoleh hasil yaitu keadaan lantai agar terlihat lebih memiliki space sehingga pekerja lebih leluasa untuk melakukan pekerjaannya. Seiri yaitu meletakkan peralatan pada tempatnya dan minyisihkan yang tidak perlu sehingga pekerja tidak membutuhkan waktu yang lama dalam menyelesaikan tugasnya.

2. Seiton

Metode seiton merupakan kelanjutan dari seiri, dimana dari hasil pemilahan yang telah dilakukan akan dilanjutkan dengan proses penataan peralatan yang telah dipilah tersebut.

\section{Seiso}

Pada tahap ini hal yang dilakukan adalah proses pembersihan. Adapun pembersihan yang dilakukan adalah pembersihan debu dan sampah dilantai produksi dan peralatan yang digunakan untuk proses pelayanan pencucian. 


\section{Seiketsu}

Pada tahap ini lebih mengarah pada proses pemantapan terhadap metode $5 \mathrm{~S}$ yang telah diterapkan. Pada tahap ini dilakukan suatu upaya bagaimana penerapan yang telah dilakukan tetap berlangsung terus-menerus bukan untuk sementara saja dengan cara pembuatan label area pencucian.

\section{Shitsuke}

Tahap ini merupakan bagian terakhir dari metode 5S. Pada bagian ini lebih memfokuskan bagaimana cara untuk membiasakan diri terhadap penerapan metode ini. untuk itu diperlukan kesadaran dari para pekerja untuk memiliki pola kerja yang sesuai dengan metode 5S demi kenyamanan dan keamaan dalam bekerja.

\section{Final Layout}

Dari perhitungan ARC kemudian dilakukan perhitunga Work sheet, block template, Activity Relationship Diagram (ARD), perhitungan productionspace requirement sheet, perhitungan Plan service area panning sheet, Perhitungan total space requirement sheet, Area template, Space relationship diagram. Sehingga diperoleh Final layout yaitu berupa rancangan akhir dari penelitian yang dapat dilihat pada Gambar

\section{KESIMPULAN}

Hal-hal penting yang dapat disimpulkan mengenai pokok bahasan dari penelitian ini adalah sebagai berikut:

1. Berdasarkan data yang dianalisa setelah usulan perbaikan tata letak didapat bahwa luas area pengeringan mobil menjadi $118 \mathrm{~m}^{2}$ yaitu dengan panjang $36 \mathrm{~m}$ x lebar $3 \mathrm{~m}$ ditambah dengan area parkir keluar panjang $2 \mathrm{~m}$ x lebar $5 \mathrm{~m}$, area pengeringan motor digabung dengan area pencucian motor dengan panjang $12.5 \mathrm{~m}$ x lebar $3 \mathrm{~m}$, area parkir mobil serta area parkir masuk tidak dirubah dikarnakan kebutuhan luas lahan yang masih memadai.

2. Berdasarkan dari data dimensi kendaraan didapat bahwa motor ukuran besar yaitu motor Tiger dengan dimensi panjang 2029mm x lebar $747 \mathrm{~mm}$ dapat memuat 5 unit pada area pengeringan motor dan 5 unit pada area pencucian motor, mobil dengan ukuran besar yaitu mobil Inova dengan dimensi panjang 4555mm x lebar 1770mm 
dapat memuat 8 unit pada area pengeringan mobil serta dapat memuat 3 unit pada area parkir masuk.

3. Dari data yang telah dianalisa didapat bahwa pada area pengeringan mobil banyak mobil yang ditinggal kan oleh pemiliknya setelah proses pelayanan selesai dan tidak ada waktu khusus untuk pengambilan oleh pemilik.

4. Adapun kesimpulan dari penelitian yang sudah dilakukan adalah Rancangan ulang tata letak fasilitas pada usaha kecil pencucian kendaran. Penelitian ini menerapkan metode 5S pada penyusunan tata letak fasilitas Alya Jaya Motor untuk memperoleh tata letak yang lebih rapi, yaitu Seiri dan Seiton pada gudang mekanik, Seiso yaitu pada gudang produksi dan semua departemen, Seiketsu dan Shitsuke yaitu pada semua departemen, sehingga pada saat pemilik usaha ingin mengajukan pembiayaan pada Bank untuk memperbesar usaha nya, dapat di setujui oleh pihak Bank.

\section{DAFTAR PUSTAKA}

Aiello, S., O’Hara, A. \& Saing, S. (2007). Systematic Layout Plantfor Baystate Benefit Services, Northeastern University Spring, www.baystatebenefits.com.

Apple, James M. (1990). Plant Layout and Material Handling ( $3^{\text {rd }}$ ed). New York. John Wiley dan Sons.

Diana Khairani Sofyan (2015). Perancangan Ulang Tata Letak Fasilitas Dengan Menggunakan Metode Konvensional Berbasis 5S. Jurnal Teknovasi Teknik Infustri Vol 02 No 2, ISSN : 2355-701X, Jurusan Teknik Industri, Universitas MalikussalehNanggroe Aceh Darussalam (NAD)

Hendri. (2010). Perencanaan Tata Letak Pabrik. Modul 10 PTLP secara sistematis. Jurusan Teknik Industri. Universitas Mercu Buana.

Merry, S,. \& Henriadi (2012). Perancangan Ulang Tata Letak Fasilitas Pabrik Tahu danPenerapan Metode 5S. Jurnal Ilmiah Teknik Industri Vol. 11, No. 2 Desember 2012, ISSN1412-6869, Jurusan Teknik Industri, Fakultas Sains dan Teknologi, UIN Sultan Syarif Kasim Simpang Baru Panam, Pekanbaru. 
DIMENSI, VOL. 8, NO. $1: 71-89$

MARET 2019

ISSN: 2085-9996

Meyers, F.E. (1993). Plant Layout and Material Handling. New Jersey. Regents/Prentice Hall, Engletuood Cliffs.

Purnomo, H,. (2004). Perencanaan dan Perancangan Fasilitas. Edisi Pertama. Graha Ilmu, Yogyakarta.

Ratnasari, Sri Langgeng. (2012). Bank dan Lembaga Keuangan Lainnya. Surabaya: UPN Press.

Wignjosoebroto, S. (2000). Pengantar Teknik dan Manajemen Industri. Penerbit Prima Printing, Surabaya.

Wignjosoebroto, S. (2009). Tata Letak Pabrik dan Pemindahan Bahan. Edisi ketiga. Penerbit: Widya Guna, Surbaya. 